\title{
INTRODUCTION
}

\section{AFTERMATH OF TRAUMA. VANCOUVER CONFERENCE 2020}

\section{Endre Koritar ${ }^{1}$}

Psychoanalytic praxis has evolved since Freud first established the basic tenets of standard technique in his Technical Papers (1912), as clinicians applied analytic concepts in their work with patients but were challenged by more regressed patients who were non-responsive to standard technique. Whereas patients with a core neurotic personality structure readily responded to the standard approach, those who formed narcissistic transferences (schizophrenias, autistic spectrum disorders, psychoses, moderate to severe personality disorders, and PTSD) were not considered amenable to analytic technique. Yet given the great demand for finding effective treatment modalities for the latter group, psychoanalytic researchers (Eissler, 1953; Ferenczi, 1930; Kernberg, 1976; Kohut, 1977; Stone, 1954) have proposed variations of standard technique that may be useful in working with this more regressed patient population. As technical advances in analytic practice made analytically informed treatment more available to more regressed patients, analysts have expanded their theoretical research and have proposed conceptual revisions of the metapsychology underlying the psychopathology they witness in their clinical work. In this context, the impact of environmental trauma on self development and its significance in developmental arrests and resulting psychopathology continue to be of interest.

As psychoanalytic praxis has moved increasingly in recent years from a metapsychology of content to a metapsychology of process (Roussillon, 2016), the impact of environmental impingements on psychic development

Endre Koritar, M.D. FRCP(C), Assistant Clinical Professor, University of British Columbia; full member, International Psychoanalytical Association. Member, Board of Directors, International Sándor Ferenczi Network; Associate Editor, American Journal of Psychoanalysis. Director, training and supervising analyst, Western Psychoanalytic Society \& Institute, Canada. 
have become increasingly appreciated (Levine, 2012), and repercussions on theory and praxis debated.

The 2020 Vancouver Conference: The Aftermath of Trauma, brought into focus for discussion, the nature of the trauma and its impact on the developing self. The invited speakers, Howard Levine, Judy Eekhoff, and Dominique Scarfone shared and debated their views on content and process.

Often, working dynamically with traumatized patients is complicated by an absence of content while process might appear to be progressing adequately. Places in the psyche where trauma has been experienced are shrouded in darkness and scotomized for good reason. Approaching such places triggers abjection, revulsion, flashbacks, nightmares, hallucinations, and terror. A psychoanalytic searchlight, attempting to shed light in these dark places is drained of its light for fear of waking phantoms buried in crypts that will then haunt the victim with the dreaded terror that, long before, had been laid to rest. As clinicians and patients courageously explore these regions, analytic audiences are the beneficiary of their insights and are provided with maps to help guide future explorers through these dark zones in the psyche.

Levine (2021) describes the nature of the darkness. Content is absent since it was never present. Experience is lived thru but not symbolized and remains as a beta element (Bion, 1962). Alpha function and containment (Bion, 1970), objectalization (Green, 2005), symbolization, figurabilty, (Botella \& Botella, 2005) and representations are disrupted, distorted, or prevented from developing (Levine, Reed \& Scarfone, 2013). The content of the trauma remains unrepresented, in darkness, yet is experienced somatically, enacted, or hallucinated until the analytic situation can provide a container. When analysis is able to galvanize the alpha function, figurability, and symbolization sufficiently, the analyst and analysand can coconstruct a meaningful narrative to serve as a container for the unrepresented state and a vehicle for making sense of past experience. But this is easier said than done! Many regressed and traumatized patients have become severely withdrawn, or undrawn (Alvarez, 2012) in an arid (or desert-ified) internal landscape, where objects are stripped of their significance, experienced as uninteresting, meaningless, and without value. These patients may have no interest in object relations nor any desire to connect with the analyst. Standard technique is inadequate to reach them and possibly even harmful (Ferenczi, 1930). Alvarez (2012) and Levine (this issue) suggest that the analyst will need to help the patient cultivate an ability to be interested in an object, and "analysts must be flexible, intuitive, and prepared to move beyond the confines of the assumptions of classical technique". These traumatically undrawn patients require the analyst to 
embark on a reclamation of meaning project, before any meaningful analytic work can be done (Alvarez, 2012). Levine describes his work with a desertified young man where his apperception and spontaneous observations of what the young man (T) was missing out on in his undrawn life injected a vitality in an affectively deadened internal landscape: "...the inter-affectivity of our object relationship [....] helped jump start something in T...". Levine's positive parental countertransference enlivened $T$ and "sparked his own capacities for thinking, imagining, and dreaming into action" (Levine, 2021).

Patients with psychic voids and unrepresented states may have been the victims of early pre-verbal trauma that left in its wake a deadened desertified internal landscape which likely will require that the therapist be lively in attempts to reclaim their internal desert landscape with intuitive and spontaneous gestures that, like a rainstorm in the desert, will germinate seeds of meaning buried under arid sands and nourish new growth of coconstructed narratives that will fill psychic voids and dead zones with new life.

Thompson (2021) elaborates on Levine's concept of an internalized desert, and asks how the analyst survives with an analysand in such an environment? Clearly, they need to find water (meaning) and Thompson suggests that Levine, struggling to survive the challenge of the aridity of the analysis, introduces his own lively experiences as a youth, exploring the big national parks. Levine noted that this enthusiasm in turn galvanized his patient, $\mathrm{T}$, to do some exploring on his own. The challenge for the analyst is to survive the aridity of the analysis and search for meaning using his apperception in guiding him, through representational imperative, to construct meaningful narratives in the analytic process.

Levine's work with $\mathrm{T}$ and his desertified internal spaces begs the question: How did the desert become a desert? How is a mind stripped of meaning and signification?

Eekhoff (2021) uses her experiences in observing the early infant and mother relationship in proposing explanatory models to understand how environmental stress may lean on the developing infantile psyche. The earliest experience of the outside world after the caesura of birth is a harmonious undifferentiated mix-up between mother and child which Balint calls Primary Love (Balint, 1968), in contrast with Freud's Primary Narcissism (1914). Grotstein (1980) calls this original state of being Background Object of Primary Identification: "...that primary process, or as Bion terms, alpha function, is the continuation of primary at-one-ment through a mystical umbilical connection in phantasy to the womb-mother" (p. 537). 
The psyche ${ }^{2}$ of the neonate remains fragile and prone to catastrophic fragmentation in reaction to environmental trauma that is experienced as a resonance of suffering (Green, 2007) that breaches the contact barrier causing tears in the fabric of the psyche (Green, 2005). Eekhoff (2021) refers to this earliest state of being as the primal position (this issue) and represents the molten core of the self (this issue) where the affective experience is intense, raw, wild, chaotic, and undifferentiated. The catastrophe can be contained through the introjection of a sensate experiencing of a skin on skin physical and mental holding of the distressed child by mother (Bick, 1968). If the containing experience is compromised and the caretaking object is physically, emotionally, or mentally absent, the infant experiences an ongoing resonance of unmodulated suffering and the trauma of a tear in the psyche which overwhelms the fragile psyche. The resulting fragmentation, described by Ferenczi as atomization of the ego (1933), can be experienced as an implosion of the self, leaving a black hole or psychic void with split-off self fragments floating in a chaotic confused internal landscape. Or, the outcome of the tear in the psychic fabric may be explosion and projection of the split-off fragments into external space which leaves behind an empty center of gravity and a sense of depletion, deflation, passivity, and drained vitality. Reverse alpha function leaves the infant persecuted by phantoms of the trauma and bizarre objects persecuting their conscious experience of the world.

Psychic development may be arrested in adhesive identification (Meltzer, 1974) fixated on the sensate (touch, sight, smell, taste, hearing) experience of the other's physical communication (soft/hard, warm/cold, sharp/smooth, loud/quiet, etc.), resulting in an autistic enclave which has been called autistic-contiguous position by Ogden (1989), the area of creation by Balint (1968), and the psychotic personality by Bion (1957). The analyst must be able to accept these projective-identifications (P-I) and survive the actual experience of these primitive states through containment, and to be able to do the work of symbolization which is the first step in the development of thinking. The move from adhesive identification to splitting and the paranoid-schizoid position and then to the depressive position is contingent on mutual communicative P-I and the containment of the molten core of raw emotional experiencing of primitive agonies presented to both analyst and analysand. Early environmental trauma had leaned on the development of the immature psyche and resulted in autistic enclaves in the child-andlater-adult. A more benevolent environmental intervention is now required through analysis to help to heal the tear in the psyche and jump start a delayed development of the mechanisms of thinking and move from presentation of the resonance of suffering, implosion, and explosion to representation in the analytic space and the co-construction of a narrative 
that will contain the terror experienced in the first instance of the trauma, and in the process, help to cohere atomized self fragments, and restore the analysand's center of gravity.

Setton-Markus (2021) discusses how Eekhoff sensitively applies these empirical models to the actual clinical work with a traumatized patient (E). Verbal interventions may be experienced as dangerous penetrations of the contact barrier threatening an implosion and fragmentation, or are projected into space leaving her patient depleted without a center of gravity. The analyst will need to feel her way along using her empathic attunement and apperception to sense how to be a good enough maternal object in providing a container for E's projections. Introjective identification results in the analyst joining with $E$ in experiencing the dread and distress in the countertransference as fear of a catastrophic and a dangerous outcome to the analysis. Both analyst and analysand exhibited courage in their determination to stay the course of the analysis despite the dire straits they at times found themselves in. Eekhoff's metabolizing and working through E's projections provided a container for the unrepresented emotional trauma with the original object and together, they found the "words to say it" where there were none beforehand. Symbolic representation and figurability led to E being able to cohere her imploded self fragments, to retrieve her projections into space, to find her center of gravity, and apply herself to find a life worth living.

Scarfone (2021) scrutinizes the process of the impact of environmental trauma on the subject, distinguishing the ego as psychic mechanism and "the I" (das Ich) as the body-psyche's experience of going on becoming ${ }^{3}$.

The impact of trauma on the self can be considered from different vertices. Self can be deviated, divided, or de-centered as a result of environmental factors leaning on self development. Scarfone considers how self development is deviated by the seduction of the enigmatic signifier implanted as a foreign body into the child's psyche representing an irritative spine that initiates a process of differentiation and structuring of libidinal and aggressive drive. In this context, the child's originary sense of going-onbeing is impacted by the drive and desire of the other, shaping the sensemaking efforts of the child. In the instance of implantation, the desire of the other, although an intrusion into the psyche and therefore traumatic, can be considered as having a structuring influence on the still immature developing psyche's ability to make sense of the experience. In the instance of forced intromission, this is experienced as a violent intrusion and compromises the child's ability to get a reliable representation of the experience. In the former situation, the trauma is of a manageable magnitude and amenable to representation, while in the latter it is overwhelming and remains unrepresented. 
On another level, we may consider that the self is divided into different topographical perspectives of conscious and unconscious. In a Cartesian manner, we might consider that forced intromission presents the immature self with overwhelming trauma that is managed by ego defenses such as dissociation, negation, denial, and disavowal, while the trauma of the implantation is managed by more mature defenses, and more readily available for representation. The combination of the nature of the trauma, and how it is managed intrapsychicaly will impact on how the self interacts with external objects.

The third layer of impact on the immature self is centeredness versus decenteredness. The infant's (and probably even the fetus') self is de-centered as a result of the "...primacy of the other in human existence and human becoming" (Scarfone, 2021). The developing immature self is impacted by the nature of the environmental object relations and relatedness that impinges on the infant's going on being. Yet "...the ego subjectively experiences itself as a center" (Scarfone this issue). Along the lines of Winnicott's (1960) conception of the self being divided into true and false expressions of going on being, Scarfone suggests that along with the self's ongoing subjective experiencing, an aspect of the self is engaged in moments of going on becoming which he calls subjectality. The subjectal is the center of action in the moment, in the sense of a self acting spontaneously, without hindrance of environmental impingements on the sense of going on being, and hence, in the moment, the self is going on becoming and moving forward towards new experiencing. The subjectal is hindered by the impacts of environmental trauma. Consequently, the object of analysis from this vertex, is working towards recovering from trauma and reinstating the dynamic process of going on becoming.

In Koritar's commentary (2021) on Scarfone's (2021) paper he expands on the discussion concerning the impact of trauma on the developing self, in citing Ferenczi's works on the topic (1932). The trauma results in a fragmentation of the ego (in the sense of psychic agency, awareness, thinking, memory), and in the void left behind the devastation, an identification with the aggressor impinges upon the tender psyche by mimicking the other's desire and aggression, but also identifying with the other's guilt resulting in the child blaming itself for the perpetration. Ferenczi (1933) uses the analogy of a teratoma to describe the process. A teratoma is a tumor consisting of foreign tissue matter. It is a foreign body growing undisturbed within the host body. This is reminiscent of Scarfone's (2021) discussion of the impact of forced intromission on the developing self. The child may also use the mechanism of autotomy (the elision of a part of the ego) shaping the immature ego in order to appease the demand of the other. There are manifold impingements on the immature developing 
psyche's going on becoming that hinder its spontaneous self expression. Psychoanalysis should ideally provide a space where healing can occur in the context of a new and benevolent object relationship facilitating the exploration of new horizons in a spiral where past scenarios are repeated in the analysis but worked through at another level causing a forward movement towards new beginnings.

The 2020 Vancouver Conference provided a forum for presenters, discussants, and participants to discuss and debate the nature of trauma and its impact on the developing self, contributing important insights concerning the environmental contribution to the early development of the self and its impact on going on being and going on becoming. The psychoanalytic community needs such forums for dialogue and debate to ensure its continued growth and going on becoming.

https://doi.org/10.1057/s11231-021-09287-x

\section{NOTES}

1. Endre Koritar, MD, FIPA, is a Training and Supervising Analyst in Western Psychoanalytic Society Institute, a branch of the Canadian Institute of Psychoanalysis, and its current Director. He is an Associate Editor of the American Journal of Psychoanalysis and has been Guest Editor of several Special Editions dedicated to publishing important papers from the International Ferenczi conferences in Toronto and Florence.

2. I use the term psyche here in the same sense as Hartmann (1950) used the term ego, in stating that ego, personality, and self have been used interchangeably in early psychoanalytic writings.

3. I would suggest that the term self may be used to encompass the ego as psychic mechanism, the subject as the seat of subjective experience, and the body-psyche as the seat of going-on-becoming. The self would be an overarching term to include the various aspects of one's sense of going-on-being (Winnicott, 1962). The discussion of the varying definitions of subject, subjectivity, subjectality, self, ego, "I," the "I," psyche, and personality is beyond the scope of this paper. I will use self in this commentary to refer to the composite ego, subject, and subjectal. It may be a useful paradigm to consider the self as analogous to a layered cake where a slice can be defined as consisting of different layers.

\section{REFERENCES}

Alvarez, A. (2012). The thinking heart. Three levels of psychoanalytic therapy with disturbed children. New York: Routledge.

Balint, M. (1968). The basic fault. New York: Bruner-Mazel.

Bick, E. (1968). The experience of skin in early object relations. International Journal of Psycho-Analysis, 49, 484-486.

Bion, W. R. (1957). The differentiation of the psychotic from the non-psychotic personalities. International Journal of Psycho-Analysis, 38, 266-275.

Bion, W. R. (1962). Learning from experience. London: Heineman. 
Bion, W. R. (1970). Attention and interpretation. London: Tavistock.

Botella, C., \& Botella, S. (2005). The work of psychic figurability: Mental states without representation. Hove, UK and New York, NY: Brunner Routledge.

Eekhoff, J. K. (2021). No words to say it: Trauma \& its aftermath. American Journal of Psychoanalysis, 81/2.

Eissler, K. R. (1953). The effect of the structure of the ego on psychoanalytic technique. Journal of the American Psychoanalytic Association, 1(1), 104-143.

Ferenczi, S. (1930). The principles of relaxation and neocatharsis, In Final contributions to the problems and methods of psycho-analysis. (pp. 108-125). London: Karnac Books. 1994.

Ferenczi, S. (1932). The Clinical Diary of Sándor Ferenczi. J. Dupont (Ed.), M. Balint \& N.Z. Jackson (Trans.) Cambridge, MA. \& London: Harvard University Press. 1988.

Ferenczi, S. (1933). Confusion of tongues between adults and the child. The language of tenderness and of passion. In Final contribution to the problems and methods of psychoanalysis. (pp. 156-167). London: Karnac Books. 1994. Also in International Journal of Psychoanalysis, 30, 225-230. 1949.

Freud, S. (1912). The technical papers. Standard Edition, Vol. 12. London: Hogarth.

Freud, S. (1914). On narcissism. Standard Edition, Vol. 12, (pp. 67-103). London: Hogarth.

Green, A. (2005). Key ideas for a contemporary psychoanalysis. Misrecognition and recognition of the unconscious. London: Routledge.

Green, A., (Ed.). (2007). Resonance of suffering: Countertransference in non-neurotic structures. London: International Psychoanalytical Association. [Reprinted London: Karnac, 2009.]

Grotstein, J. S. (1980). A proposed revision of the psychoanalytic concept of primitive mental states-Part I: Introduction to a newer psychoanalytic metapsychology. Contemporary Psychoanalysis, 16, 479-546.

Hartmann, H. (1950). Comments on the psychoanalytic theory of the ego. In Essays on ego psychology. (pp. 113-141). New York: International Universities Press. 1964.

Kernberg, O. F. (1976). Technical considerations in the treatment of borderline personality organization. Journal of the American Psychoanalytic Association, 24, 795-829.

Koritar, E. (2021). Discussion of Dominique Scarfone's "trauma, subjectivity, and subjectality." American Journal of Psychoanalysis, 81/2.

Kohut, H. (1977). The restoration of the self. New York: International Universities Press.

Levine, H. B. (2012). The colourless canvas: Representation, therapeutic action and the creation of mind. International Journal of Psycho-Analysis, 93, 607-629.

Levine, H. B. (2021). Further thoughts on trauma, process and representation. American Journal of Psychoanalysis, 81/2.

Levine, H. B., Reed, G. S., \& Scarfone, D. (Eds.). (2013). Unrepresented states and the construction of meaning. Clinical and theoretical contributions. London: Karnac.

Meltzer, D. (1974). Adhesive identification. In A. Hahn (Ed.), Sincerity and other works: The collected papers of Donald Meltzer. (pp. 335-350). London: Karnac.

Ogden, T. H. (1989). On the concept of an autistic-contiguous position. International Journal of Psycho-Analysis, 70, 127-140. 
Roussillon, R. (2016). Pour introduire le travail sur la symbolisation primaire. [To introduce the work on primary symbolization]. Revue Francaise de Psychanalyse, 80, 813-831.

Setton-Markus, J. (2021). Discussion of Judy Eekhoff's paper, no words to say it: Trauma \& its aftermath. American Journal of Psychoanalysis, 81/2.

Scarfone, D. (2021). Trauma, subjectivity, and subjectality. American Journal of Psychoanalysis, 81/2.

Stone, L. (1954). The widening scope for indications for psychoanalysis. Journal of the American Psychoanalytic Association, 2, 567-594.

Thompson, D. (2021). Discussion of Howard B. Levine's paper, further thoughts on trauma, process and representation. American Journal of Psychoanalysis, 81/2.

Winnicott, D. W. (1960). Ego distortion in terms of true and false self. In The maturational processes and the facilitating environment. (pp. 140-152). London: Karnac. 1965.

Winnicott, D. W. (1962). Ego integration in child development. In The maturational processes and the facilitating environment. (pp. 56-63). London: Karnac. 1965.

Publisher's Note Springer Nature remains neutral with regard to jurisdictional claims in published maps and institutional affiliations. 